\title{
A STONE RUIN AT SË-T̃SAK, GUATEMALA
}

\section{BY ROBERT BURKITT}

This brief description and the accompanying diagrams are of a stone ruin at Së-tsak, in the land of Sepacuité, about four leagues east of the village of Senahú, province of Alta Vera Paz, Guatemala, which was visited by the writer in 1896 . The ruin blocks the summit of a narrow pass, and the woods in the immediate vicinity are of old growth, and not pines. The western approach, which is very steep, is cut square across by the outlying wall, at A in plate IV and figure 3. This wall, or stair, lies due north and south, or very nearly, and forms the edge of a sort of terrace behind the main

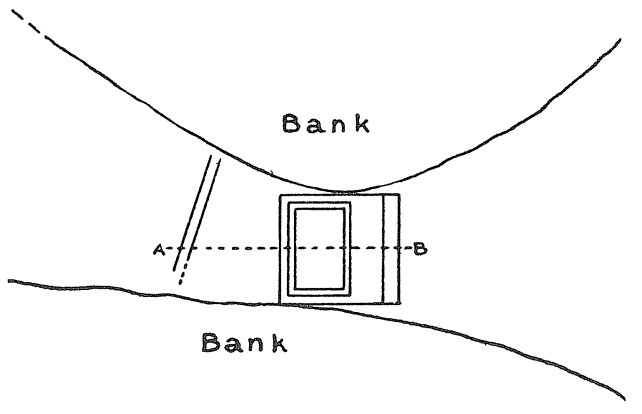

FIG. 3. - Situation of the ruin.

structure. The main structure is not parallel with that wall, but faces the opening of the wall on the other side; the pass shifts round at the top, as indicated in the figure. The banks are steep on both hands and abut against the sides of the structure to the height of the first platform, as shown by the profile $\mathrm{L}, \mathrm{M}$, in plate IV. At the front corners the space left between the receding bank and the side of the structure, on each hand, is filled across with tiers of stone, now covered with rubbish and not shown in the drawings.

The front of the ruin is sunk toward the middle, and the size of the steps is averaged. The front view of the main structure in outline, restored, is shown in plate $\mathrm{V}$. The point of view is $\mathrm{P}$, shown on the plan (pl. IV), fifteen feet from the base, on a line with the 
side, and level with the top (c), the center of perspective - to be four inches from the eye.

The stone of which the structure is built is limestone, and not hard. Squared stones are found only in the front, or easterly side, of the ruin, where the stones are larger than in other parts. The largest are not more than two and one-half feet long. No mortar was used. The interior was not explored. The back terraces appear to have been paved, at least along the foot of the main structure. The stair behind was probably much deeper than the present surface at $\mathrm{A}$.

$$
\text { Measurements (in English feet) }
$$

Main structure. Eastern side : Total height, near B....

Length from north to south........... 37

Width from east to west upper surface. $35 \cdot 3$

Height of lower terrace............... 2.2

Height of four upper terraces .......... 3

Breadth of terraces .................... 1.3

Length of steps......................... 9

Height of steps......................... I.5

Breadth of steps....................... .65

Western side: Height

Base of main structure to western steps near A ............................. 29.5

Height of two corner steps ............ 2

Height of third step .................. 3

Height of upper step .................. 2

From eastern end of main structure to base of upper structure ............. 10.7

From western end of main structure to base of upper structure........... 3.8

From northern and southern banks to base of upper structure........... 3

Upper structure : Length of lower platform ............. 3I

Width of lower platform ............... 20.8

Height of lower platform .............. 4.8

Length of upper platform ............. 26

Width of upper platform.............. I 5.7

Height of upper platform ............. 2

Width of terrace around base of upper platform............................ 2.5

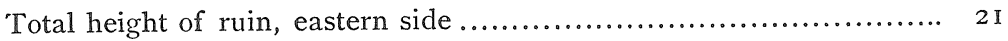

Total height of ruin, western side.................................. I 1.5

SENAHú,

Guatemala. 


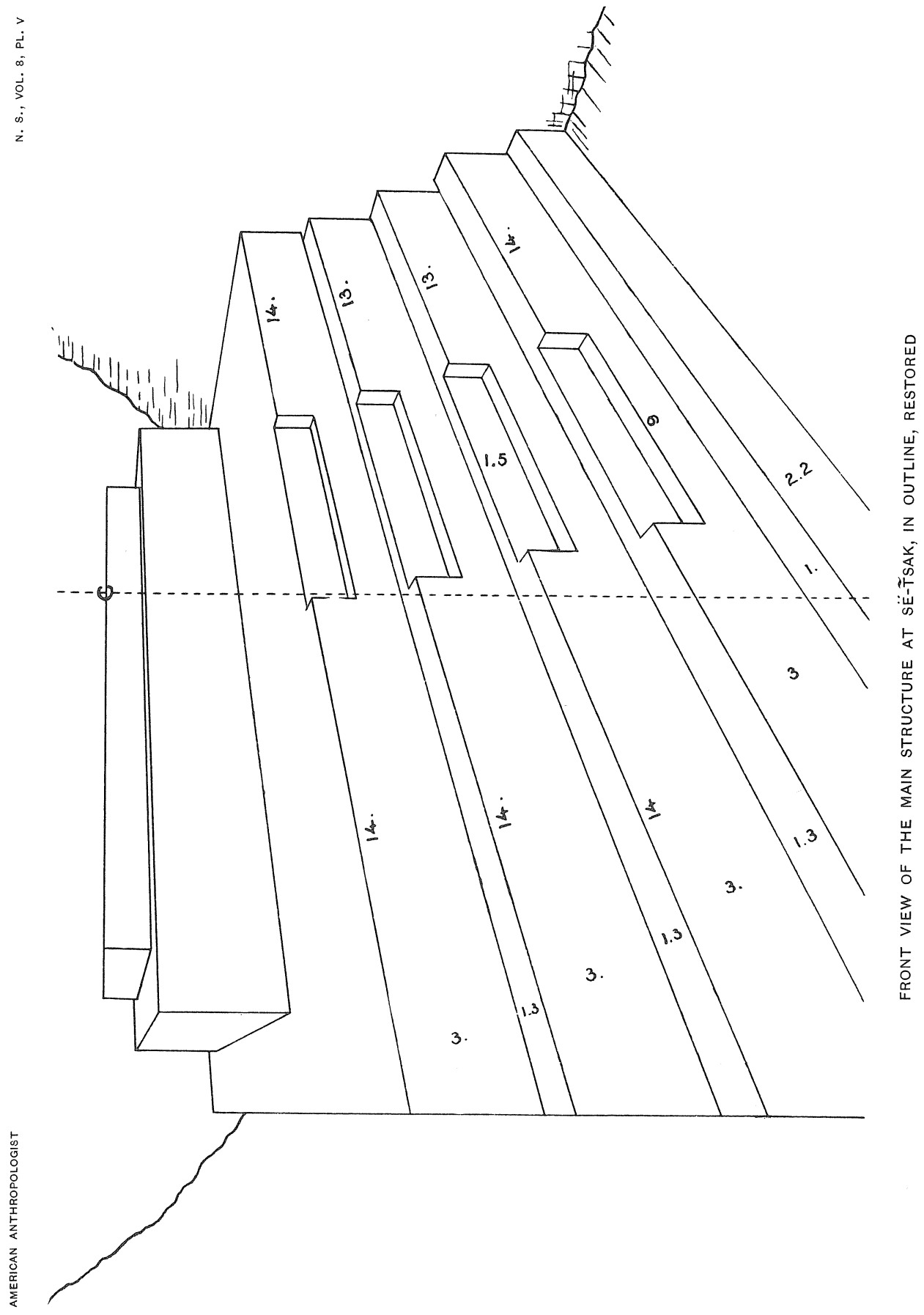

